\title{
Synthesis and biological activity of $N^{\prime}$-(substituted pyrimidin-2-yl)- $N$-dichlorochrysanthemoyl thioureas and their fused heterocyclic compounds
}

\author{
Sijia Xue*, Yanling Guo, Jingzhi Li, Shaoyong Ke and Liping Duan \\ College of Life and Environmental Science, Department of Chemistry, Shanghai Normal University, \\ Shanghai, 200234, P. R. China \\ E-mail : ylguo420@163.com
}

Manuscript received 25 June 2004, accepted 24 November 2004

\begin{abstract}
Five $N^{\prime}$-(substituted pyrimidin-2-yl)- $N$-dichlorochrysanthemoyl thioureas (5a-5e) were synthesized from corresponding dichlorochrysanthemic acid in three steps. And two dichlorochrysanthemoylimino-2H-1,2,4-thiadiazolo[2,3-a]pyrimidines were prepared by oxidizing cyclization of $5 \mathrm{a}, 5 \mathrm{~b}$. The structures of these novel target compounds were confirmed by IR, ${ }^{1} \mathrm{H}$ NMR and elemental analyses. The preliminary biological activity tests indicated that some target compounds had better insecticidal activity, fungicidal activity and so on mulriple efficacies.
\end{abstract}

The acyl thiourea compounds are well known for their better pesticidal activity, fungicidal activity, antivirus activity and regulating activity for plant growth ${ }^{1,2}$. In addition, they are very important intermediates in organic synthesis ${ }^{3-5}$. During recent years, the pseudo cinerins have been widely developed as chiral pesticides with high efficiency, have good pesticidal activity ${ }^{6}$ and regulating activity for plant growth as well ${ }^{7}$. In th process of searching for new active materials and precursor compounds, we adopted the method of combining active groups together to synthesize $N^{\prime}$-(substituted pyrimidin-2-yl)- $N$-dichlorochrysanthemoyl thioureas (5a-5e) by bring dichlorochrysanthemic acid in the acyl thiourea structure with pyrimidine ring. According to the survey of literature, $2 H-1,2,4$-thiadiazolo[2,3a]pyrimidine derivatives are another noticeable ALS inhibitor after the advent of sulfonylurea herbicides, which have comparative herbicidal activity, yet with superior selectivity ${ }^{8-11}$. Two dichlorochry-santhemoylimino- $2 H-1,2,4-$ thiadiazolo[2,3-a]pyrimidines $(\mathbf{6 a}, \mathbf{6} \mathbf{b})$ were prepared from (5a, 5b) by employing $\mathrm{Br}_{2}$ as the oxidant ${ }^{12,13}$. We expected to make full use of each active group by linking acyl thiourea with $2 H-1,2,4-$ thiadiazolo[2,3-a]pyrimidine effectively. Moreover, these compounds contain an inherently weak $\mathrm{N}$ $\mathrm{S}$ bond which can benefit plant's absorption and metabolism. In fact, this is where their good selectivity exists. The structures of these novel target compounds were confirmed by IR, ${ }^{1} \mathrm{H}$ NMR and elemental analyses. The preliminary biological activity tests indicated that some target compounds had better insecticidal activity, fungicidal activity and so on mulriple efficacies.

The process for synthesis of target compounds is in Scheme 1.

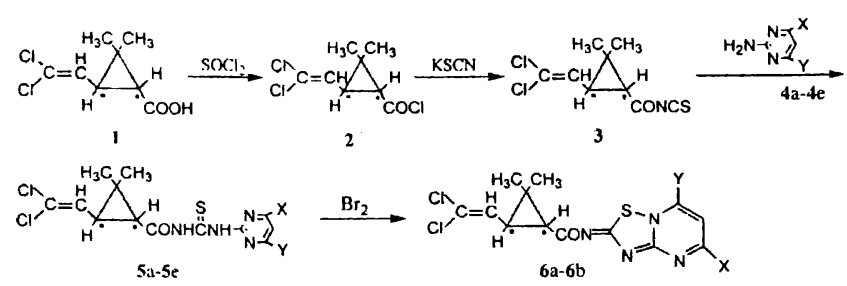

(a) $\mathrm{X}=\mathrm{Y}=\mathrm{OCH}_{3}$; (b) $\mathrm{X}=\mathrm{Y}=\mathrm{OC}_{2} \mathrm{H}_{5}$; (c) $\mathrm{X}=\mathrm{Y}=\mathrm{CH}_{3}$; (d) $\mathrm{X}=$ $\mathrm{OCH}_{3}, \mathrm{Y}=\mathrm{CH}_{3} ;(\mathbf{e}) \mathrm{X}=\mathrm{OCC}_{2} \mathrm{H}_{5}, \mathrm{Y}=\mathrm{CH}_{3}$

Scheme 1

\section{Experimental}

\section{Reagents and apparatus :}

All precursor substances are commercial products of chemical or analytical grade purity. Sulfuryl chloride was redistilled before use and potassium thiocyanate was dried before use. 2-Amino-4,6-disubstituted pyrimidines (4) were prepared by the literature method ${ }^{14}$. Dichlorochrysanthemic acid is a white solid (m.p. $60-62^{\circ} \mathrm{C}$ ).

The melting point was determined on an XT4A micro digital melting point apparatus, and were uncorrected. The $\mathrm{C}, \mathrm{H}$ and $\mathrm{N}$ analyses were repeated twice by elemental microanalyses. The IR spectra were recorded in the region $4000-400 \mathrm{~cm}^{-1} \mathrm{KBr}$ discs on a Nicolet 5DX FT-IR spectrophotometer. The ${ }^{1} \mathrm{H}$ NMR spectra were obtained on a Varian-300-54 spectrometer in $d_{6}$-DMSO using TMS as internal reference.

\section{Procedure :}

The procedure for the synthesis of the target compounds 
5a-5e, 6a-6b is as follows :

Dichlorochylsanthemic acid $(0.01 \mathrm{~mol})$ as dissolved in petroleum ether $(5 \mathrm{~mL})$ in a dried round-bottomed flask containing a magnetic stirrer, and dripped the mixture of sulfuryl chloride $(0.015 \mathrm{~mol})$ and petroleum ether $(5 \mathrm{~mL})$ at about $0^{\circ} \mathrm{C}$, after refluxing for $2 \mathrm{~h}$, the system was left to $\mathrm{cool}$ at room temperature. The petroleum ether and excessive sulfuryl chloride were removed under reduced pressure to give a clear solution of dichlorochrysanthemoyl chloride 2 , which was added to a solution of potassium thiocyanate $(0.015 \mathrm{~mol})$ in $10 \mathrm{~mL}$ of absolute acetonitrile. The reaction mixture was stirred and refluxed for bout $45 \mathrm{~min}$, the precipitate in the solution was filtered off to yield an orange-red solution 3 . Then equimolar quantity of 4,6-disubstituted-2-amino pyrimidine 4 was added to react under refluxed temperature for about $3 \mathrm{~h}$. In the end, the resulting precipitate was collected by filtration and recrystallized from DMF-EtOH- $\mathrm{H}_{2} \mathrm{O}$ to yield the target compound 5. To a solution of compound $\mathbf{5 a}, \mathbf{5 b}$ in $15 \mathrm{ml}$ of $\mathrm{CHCl}_{3}$, equimolar quantity of bromine was drop added at water-ice bath. After addition, the flask with the reaction mixture was stirred at room temperature for about several hours, and the process of the reaction was monitored by TLC. At the end of the reaction, the resulting precipitate was collected by filtration and recrystallized from DMF-EtOH- $\mathrm{H}_{2} \mathrm{O}$ to yield target compound 6a, $\mathbf{6 b}$.

\section{Biological activity test :}

The biological activity was evaluated with the standard bioactivity test procedures of Shanghai Branch of National Pesticide R \& D South Central in China. All the target compounds were tested by their herbicidal activity, insecticidal activity and fungicidal activity.

\section{Results and discussion}

Characterization of target molecules :

$N^{\prime}-($ Substituted pyrimidin-2-yl)-N-dichlorochrysanthemoyl thioureas (5a-5e) :

TM 5a Yield $78 \%$, m.p. $159-162^{\circ} \mathrm{C}$ (Found : C, 44.69; $\mathrm{H}, 4.27 ; \mathrm{N}, 13.60$. Calcd. for $\mathrm{C}_{15} \mathrm{H}_{18} \mathrm{Cl}_{2} \mathrm{~N}_{4} \mathrm{O}_{3} \mathrm{~S}: \mathrm{C}, 44.45$; $\mathrm{H}, 4.48$; N,13.82\%); IR $\left(\mathrm{cm}^{-1}\right) 3221,2969(\mathrm{~N}-\mathrm{H}), 1701$ $(\mathrm{C}=\mathrm{O}), 1607(\mathrm{C}=\mathrm{N}), 1235(\mathrm{C}=\mathrm{S}) ;{ }^{1} \mathrm{H}$ NMR $\left(d_{6}\right.$-DMSO) 1.22 $\left(3 \mathrm{H}, \mathrm{s}, \mathrm{CH}_{3}\right), 1.30\left(3 \mathrm{H}, \mathrm{s}, \mathrm{CH}_{3}\right), 2.25(1 \mathrm{H}, \mathrm{q}, \mathrm{CH}), 2.49(1 \mathrm{H}$, d, $\mathrm{CH}), 4.00\left(6 \mathrm{H}, \mathrm{s}, 2 \mathrm{OCH}_{3}\right), 6.05\left(1 \mathrm{H}, \mathrm{s}, \mathrm{Py}-5^{\prime}-\mathrm{H}\right), 6.10$ $(1 \mathrm{H}, \mathrm{d}, \mathrm{C}=\mathrm{CH}), 11.95(1 \mathrm{H}, \mathrm{s}, \mathrm{NH}), 12.60(1 \mathrm{H}, \mathrm{s}, \mathrm{NH})$.

TM 5b Yield $74 \%$, m.p. $128-132^{\circ} \mathrm{C}$ (Found: C, 47.33; $\mathrm{H}, 5.36 ; \mathrm{N}, 12.71$. Calcd. for $\mathrm{C}_{17} \mathrm{H}_{22} \mathrm{Cl}_{2} \mathrm{~N}_{4} \mathrm{O}_{3} \mathrm{~S}: \mathrm{C}, 47.12$; $\mathrm{H}, 5.12$; N, 12.93\%); IR $\left(\mathrm{cm}^{-1}\right) 3232,2791(\mathrm{~N}-\mathrm{H}), 1702$ $(\mathrm{C}=\mathrm{O}), 1604(\mathrm{C}=\mathrm{N}), 1225(\mathrm{C}=\mathrm{S})$; ${ }^{1} \mathrm{H}$ NMR $\left(d_{6}\right.$-DMSO)
1.20-1.40 (12 $\mathrm{H}, \mathrm{m}, 2 \mathrm{OCH}_{2} \mathrm{CH}_{3}$ and $\left.2 \mathrm{CH}_{3}\right), 2.20(\mathrm{lH}, \mathrm{q}$, $\mathrm{CH}), 2.50(\mathrm{lH}, \mathrm{d}, \mathrm{CH}), 4.28\left(4 \mathrm{H}, \mathrm{q}, 2 \mathrm{OCH}_{2} \mathrm{CH}_{3}\right), 5.75(1 \mathrm{H}$, $\mathrm{d}, \mathrm{C}=\mathrm{CH}), 5.80\left(1 \mathrm{H}, \mathrm{s}, \mathrm{Py}-5^{\prime}-\mathrm{H}\right), 8.50(1 \mathrm{H}, \mathrm{s}, \mathrm{NH}), 13.40$ $(1 \mathrm{H}, \mathrm{s}, \mathrm{NH})$.

TM 5c Yield $80 \%$, m.p. $180-181^{\circ} \mathrm{C}$ (Found : C, 48.02; $\mathrm{H}, 4.99 ; \mathrm{N}, 14.88$. Calcd. for $\mathrm{C}_{15} \mathrm{H}_{18} \mathrm{Cl}_{2} \mathrm{~N}_{4} \mathrm{OS}: \mathrm{C}, 48.26$; $\mathrm{H}, 4.86 ; \mathrm{N}, 15.01 \%)$; IR $\left(\mathrm{cm}^{-1}\right) 3174,2951(\mathrm{~N}-\mathrm{H}), 1705$ $(\mathrm{C}=\mathrm{O}), 1599(\mathrm{C}=\mathrm{N}), 1239(\mathrm{C}=\mathrm{S}) ;{ }^{1} \mathrm{H}$ NMR $\left(d_{6}\right.$-DMSO) 1.20 $\left(6 \mathrm{H}, \mathrm{s}, \mathrm{CH}_{3}\right), 1.25\left(6 \mathrm{H}, \mathrm{s}, \mathrm{CH}_{3}\right), 2.20(1 \mathrm{H}, \mathrm{q}, \mathrm{CH}), 2.43(1 \mathrm{H}$, d, $\mathrm{CH}), 6.42(\mathrm{lH}, \mathrm{d}, \mathrm{C}=\mathrm{CH}), 6.80\left(1 \mathrm{H}, \mathrm{s}, \mathrm{Py}-5^{\prime}-\mathrm{H}\right), 8.80$ (1H, s, NH), $14.00(1 \mathrm{H}, \mathrm{s}, \mathrm{NH})$.

TM 5d Yield $84 \%$, m.p. $177-179^{\circ} \mathrm{C}$ (Found : C, 46.48; $\mathrm{H}, 4.44 ; \mathrm{N}, 14.16$. Calcd. for $\mathrm{C}_{15} \mathrm{H}_{18} \mathrm{Cl}_{2} \mathrm{~N}_{4} \mathrm{O}_{2} \mathrm{~S}: \mathrm{C}, 46.28$; $\mathrm{H}, 4.66$; N,14.39\%); IR $\left(\mathrm{cm}^{-1}\right) 3186,2954(\mathrm{~N}-\mathrm{H}), 1704$ $(\mathrm{C}=\mathrm{O}), 1600(\mathrm{C}=\mathrm{N}), 1232(\mathrm{C}=\mathrm{S}) ;{ }^{1} \mathrm{H}$ NMR $\left(d_{6}\right.$-DMSO) 1.22 $\left(3 \mathrm{H}, \mathrm{s}, \mathrm{CH}_{3}\right), 1.29\left(3 \mathrm{H}, \mathrm{s}, \mathrm{CH}_{3}\right), 2.22(1 \mathrm{H}, \mathrm{q}, \mathrm{CH}), 2.45(3 \mathrm{H}$, $\left.\mathrm{s}, \mathrm{CH}_{3}\right), 2.50(\mathrm{HH}, \mathrm{d}, \mathrm{CH}), 3.93\left(3 \mathrm{H}, \mathrm{s}, \mathrm{OCH}_{3}\right), 6.23(1 \mathrm{H}, \mathrm{s}$, $\left.\mathrm{Py}-5^{\prime}-\mathrm{H}\right), 6.40(1 \mathrm{H}, \mathrm{d}, \mathrm{C}=\mathrm{CH}), 8.90(1 \mathrm{H}, \mathrm{s}, \mathrm{NH}), 13.40(1 \mathrm{H}$, s, NH).

TM 5e Yield 83\%, m.p. $133-135^{\circ} \mathrm{C}$ (Found : C, 47.83; $\mathrm{H}, 5.21 ; \mathrm{N}, 14.07$. Calcd. for $\mathrm{C}_{16} \mathrm{H}_{20} \mathrm{Cl}_{2} \mathrm{~N}_{4} \mathrm{O}_{2} \mathrm{~S}: \mathrm{C}, 47.65$; $\mathrm{H}, 5.00 ; \mathrm{N}, 13.89 \%)$; IR $\left(\mathrm{cm}^{-1}\right) 3218,2973(\mathrm{~N}-\mathrm{H}), 1689$ $(\mathrm{C}=\mathrm{O}), 1605(\mathrm{C}=\mathrm{N}), 1240(\mathrm{C}=\mathrm{S}) ;{ }^{1} \mathrm{H}$ NMR $\left(d_{6}\right.$-DMSO) 1.22-1.40 (9H, m, $\mathrm{OCH}_{2} \mathrm{CH}_{3}$ and $\left.2 \mathrm{CH}_{3}\right), 2.23(1 \mathrm{H}, \mathrm{q}, \mathrm{CH})$, $2.48(1 \mathrm{H}, \mathrm{d}, \mathrm{CH}), 2.50\left(3 \mathrm{H}, \mathrm{s}, \mathrm{CH}_{3}\right), 4.50\left(2 \mathrm{H}, \mathrm{q}, \mathrm{OCH}_{2} \mathrm{CH}_{3}\right)$, $6.40(1 \mathrm{H}, \mathrm{d}, \mathrm{C}=\mathrm{CH}), 6.65\left(1 \mathrm{H}, \mathrm{s}, \mathrm{Py}-5^{\prime}-\mathrm{H}\right), 8.50(1 \mathrm{H}, \mathrm{s}, \mathrm{NH})$, 13.80. (1 H, s, NH).

Dichlorochrysanthemoylimino-2H-1,2,4-thiadiazolol2,3-alpyrimidines (6a-6b) :

TM 6a Yield $78 \%$, m.p. $131-132^{\circ} \mathrm{C}$ (Found : C, 44.50; $\mathrm{H}, 3.72 ; \mathrm{N}, 13.76$. Calcd. for $\mathrm{C}_{15} \mathrm{H}_{16} \mathrm{Cl}_{2} \mathrm{~N}_{4} \mathrm{O}_{3} \mathrm{~S}: \mathrm{C}, 44.67$; $\mathrm{H}, 3.97$; N, 13.90\%); IR $\left(\mathrm{cm}^{-1}\right) 1720(\mathrm{C}=\mathrm{O}), 1604(\mathrm{C}=\mathrm{N})$; ${ }^{1} \mathrm{H} \mathrm{NMR}\left(d_{6}\right.$-DMSO) $1.24\left(3 \mathrm{H}, \mathrm{s}, \mathrm{CH}_{3}\right), 1.28\left(3 \mathrm{H}, \mathrm{s}, \mathrm{CH}_{3}\right)$, $2.30(1 \mathrm{H}, \mathrm{m}, \mathrm{CH}), 3.82\left(3 \mathrm{H}, \mathrm{s}, \mathrm{OCH}_{3}\right), 3.96\left(3 \mathrm{H}, \mathrm{s}, \mathrm{OCH}_{3}\right)$, $5.40\left(1 \mathrm{H}, \mathrm{s}, \mathrm{Py}-5^{\prime}-\mathrm{H}\right), 6.18(1 \mathrm{H}, \mathrm{q}, \mathrm{CH}), 8.28(1 \mathrm{H}, \mathrm{s}, \mathrm{C}=\mathrm{CH})$.

TM 6b Yield $82 \%$, m.p. $126-129^{\circ} \mathrm{C}$ (Found : C, 47.54; $\mathrm{H}, 4.42 ; \mathrm{N}, 12.70$. Calcd. for $\mathrm{C}_{17} \mathrm{H}_{20} \mathrm{Cl}_{2} \mathrm{~N}_{4} \mathrm{O}_{3} \mathrm{~S}: \mathrm{C}, 47.33$; $\mathrm{H}, 4.64 ; \mathrm{N}, 12.99 \%)$; IR $\left(\mathrm{cm}^{-1}\right) 1728(\mathrm{C}=\mathrm{O}), 1600(\mathrm{C}=\mathrm{N})$; ${ }^{1} \mathrm{H}$ NMR $\left(d_{6}\right.$-DMSO $) 1.16-1.32\left(12 \mathrm{H}, \mathrm{m}, 2 \mathrm{CH}_{3}\right.$ and $\left.2 \mathrm{OCH}_{2} \mathrm{CH}_{3}\right), 2.23(\mathrm{H}, \mathrm{m}, \mathrm{CH}), 4.28\left(2 \mathrm{H}, \mathrm{q}, \mathrm{OCH}_{2} \mathrm{CH}_{3}\right)$, $4.35\left(2 \mathrm{H}, \mathrm{q}, \mathrm{OCH}_{2} \mathrm{CH}_{3}\right), 5.35\left(1 \mathrm{H}, \mathrm{s}, \mathrm{Py}^{\prime}-\mathrm{H}\right), 5.78(1 \mathrm{H}, \mathrm{q}$, $\mathrm{CH}), 7.90(1 \mathrm{H}, \mathrm{s}, \mathrm{C}=\mathrm{CH})$.

The structures of all newly synthesized compounds $\mathbf{5 , 6}$ were assigned on the basis of their elemental analyses and spectroscopic data, IR and ${ }^{1} \mathrm{H}$ NMR. All compounds of series 5 had strong $\mathrm{N}-\mathrm{H}$ absorption at about $3220 \mathrm{~cm}^{-1}$, and at $2960 \mathrm{~cm}^{-1}$, they also had absorption band. The IR (KBr) spectrum displayed absorption at about $1690-1710 \mathrm{~cm}^{-1}$, 
$1600 \mathrm{~cm}^{-1}$ and $1200 \mathrm{~cm}^{-1}$, which were assigned to $\mathrm{C}=\mathrm{O}$, $\mathrm{C}=\mathrm{N}$ and $\mathrm{C}=\mathrm{S}$ functions respectively. The medium-strong $v_{C=O}$ band in the IR spectra of all the compounds of series 5 appeared at $1690-1710 \mathrm{~cm}^{-1}$, apparently decreasing in wavenumber compared with the ordinary carbonyl absorption $\left(1730 \mathrm{~cm}^{-1}\right)$. The formation of $\mathrm{H}$-bond inside these molecules lead the magnification of their polarity, so the strength of their double bond decreased, and their absorption moved to lower wavenumber. This is not possible in compounds of series $\mathbf{6}$, hence, their absorption of $\mathrm{C}=\mathrm{O}$ was at comparatively higher wavenumber. Even though, there was delocalized pi-bond in these compounds, the wavenumber was not so high as the ordinary carbonyl, at about $1720 \mathrm{~cm}^{-1}$. The ${ }^{1} \mathrm{H}$ NMR $\left(d_{6}\right.$-DMSO) spectrum exhibited the quartet and doublet signals at about $\delta 2.20$ and $\delta$ 2.45 were assigned to two protons of the three-membered ring. That's because that the hardly rotating single bonds of the three-membered ring made two different protons. Similarly, the two methyls on the three-membered ring had different absorption, but sometimes they overlapped together. The double bond $\mathrm{C}=\mathrm{C}$ was substituted by chlorines, the chemical shift of its protons appeared at about $6.35 \mathrm{ppm}$. Most of the compounds of series 5 exhibited signals at 8.80 $9.15 \mathrm{ppm}$ and $13.40-14.00 \mathrm{ppm}$. These are assigned to the

\begin{tabular}{|c|c|c|c|c|c|c|}
\hline \multicolumn{7}{|c|}{ Table 1. Insecticidal activity } \\
\hline \multirow[t]{2}{*}{ Compd. } & \multirow{2}{*}{$\begin{array}{l}\text { Conc. } \\
\text { (ppm) }\end{array}$} & \multirow{2}{*}{$\begin{array}{c}\text { Test } \\
\text { insects }\end{array}$} & \multicolumn{3}{|c|}{ Mortality } & \multirow{2}{*}{$\begin{array}{c}\text { Mortality rate } \\
72 \mathrm{~h}(\%)\end{array}$} \\
\hline & & & $24 \mathrm{~h}$ & $48 \mathrm{~h}$ & $72 \mathrm{~h}$ & \\
\hline $5 \mathbf{a}$ & 50 & 43 & 15 & 28 & 35 & 81.40 \\
\hline $\mathbf{5 b}$ & 50 & 22 & 0 & 0 & 6 & 27.27 \\
\hline 5d & 50 & 30 & 8 & 26 & 30 & 100.00 \\
\hline $6 \mathbf{a}$ & 50 & 23 & 3 & 15 & 21 & 91.30 \\
\hline
\end{tabular}

two $\mathrm{N}-\mathrm{H}$. The chemical shift of the proton of pyrimidine ring $\left(\mathrm{Py}-5^{\prime}-\mathrm{H}\right)$ can change greatly, just relied on the different substituents.

The biological activities of all the newly synthesized compounds were also evaluated. The preliminary test showed that some target compounds had better insecticidal activity, fungicidal activity. The insecticidal and fungicidal activities of some active compounds are given in the following Tables.

The mortality rate of compound $\mathbf{5 d}$ could reach $100 \%$ in $72 \mathrm{~h}$. The excellent insecticidal activity implied its prosperous future on the basis of deep research. Meanwhile, the
Table 2. Fungicidal activity

\begin{tabular}{cccc} 
Compd. & $\begin{array}{c}\text { Conc. } \\
(\mathrm{mg} / \mathrm{L})\end{array}$ & $\begin{array}{c}\text { Colletotrichum } \\
\text { lagenarium }(\%)\end{array}$ & $\begin{array}{c}\text { Sphaerotheca } \\
\text { fuliginea }(\%)\end{array}$ \\
5a & 1000 & 62 & 60 \\
5b & 1000 & 84 & 60 \\
5d & 1000 & 77 & 50 \\
\hline
\end{tabular}

experiment showed that compound $\mathbf{6 a}$ had better insecticidal activity.

According to the results in Table 2, the caution of compounds $\mathbf{5 b}$ and $\mathbf{5 d}$ against Colletotrichum lagenarium got $84 \%$ and $77 \%$ respectively, the better efficiency of these compounds indicated the value of further experiments.

\section{Acknowledgement}

The research was supported by the Develop Fund of Science and Technology of Shanghai City. The preliminary biological activities were finished by Shanghai Branch of National Pesticide R \& D South Central, China.

\section{References}

1. R. Y. Chen and H. L. Wang, Chem. J. Chin. Univ., 1995, 16, 1229.

2. A. Jurasek, P. Safar and V. Zvalk, Chem. Pap., 1987, 4, 693 (Chem. Abstr., 109, 37772).

3. M. R. Elmoyhayar, J. Heterocyclic Chem., 1984, $21,781$.

4. T. B. Wei, Chem. Magazine., 1995, 1, 20.

5. Z. Y. Zhang and H. X. Lin, Chem. J. Chin. Univ., 1992, 13, 936.

6. M. Elliott, A. W. Farnham and N. F. Janes, Nature, 1974, 248, 710.

7. B. Crammer, Z. Goldschmidt, R. Ikan and H. Spiegelstein, J. Agri. Food Chem., 1985, 33, 1148.

8. K. Kamala, P. Rao and K. Reddy, Synth. Commun., 1989, 13-14, 2621.

9. N. Okajima, I. Aoki, T. Kuragano and Y. Okada, Pestic. Sci., 1991, 32, 91 .

10. N. Okajima, I. Aoki and Y. Okada, Pestic. Sci., 1991, 32, 265.

11. R. Bellina and F. Russel, US 5069709, 1992 (Chem. Abstr., 1992, 116, 151784).

12. G. Y. Sarkis and E. D. Faisal, J. Heterocyclic Chem., 1985, 22, 137.

13. H. N. Wingfield, J. Am. Chem. Soc., 1953, 75, 4364.

14. S. J. Xue and D. Y. Tan, J. Central China Norm. Univ., 1998, 28, 77. 